\title{
Povýšení a přijetí do panského stavu jako vrchol i epilog rodových dějin Rájeckých z Mírova
}

\author{
MAREK STARÝ
}

Stary, Marek: Granting Lordship and Admission to the Estate of Lords as both the Peak and the Epilogue of Rájeckýs' of Mírov Family History

The study is concerned with the last member of the Moravian noble family Rájeckýs of Mirov. In the year 1602, Jan Rájecký of Mírov received an imperial decree proclaiming him a lord. However, this privilege did not mean he really became a member of higher nobility - he had to be accepted by other lords at the Land Diet. It took place at the beginning of the next year, but in Bohemia instead of Moravia. A few weeks later he unexpectedly died, so his promotion and admission were the epilogue of the family history at the same time. The study particularizes Jan's biographical data and explains the legal relevance of individual acts related to his social rise.

Key Words Czech Legal History; Estate of Lords; Land Diet; Nobility; Royal Decree doi.org/10.15452/Historica.2020.11.0008

Contact Univerzita Karlova, starym@prf.cuni.cz

Přelom 16. a 17. století představuje v českých dějinách mimořádně zajímavé a dosti dynamické období. Přeskupovaly se v něm politické síly, jejichž následný urputný střet rozhodl o směru dalšího vývoje českého státu a zároveň odstartoval celoevropský konflikt, který trval dlouhá tři desetiletí.

Za součást uvedeného přeskupování je možné považovat také dalekosáhlé proměny ve složení stavovských korporací Českého království (a nejinak též Moravského markrabství). Pokud jde o stav panský, byly tyto proměny bezprostředně vyvolány lavinovitým vymíráním velkého množství starobylých aristokratických rodů, jehož byli současníci v tomto období svědky. ${ }^{1}$ Pokud si ovšem měla vyšší šlechta uchovat rozhodující mocenské postavení v zemi, musela na tento nepříznivý demografický vývoj reagovat a doplňovat své řady bud' o přistěhovalé cizince, ${ }^{2}$ nebo - především - o nejbohatší a nejvlivnější př́slušníky nižšího šlechtického stavu, tedy rytířstva. Podle zemských desk bylo takto v období let 1541-1620 mezi pány na půdě českého zemského sněmu přijato celkem

\footnotetext{
Blíže HONC, Jaroslav: Populační vývoj šesti generací 125 českých panských rodů v letech 1502-1794. Historická demografie 3, 1969, s. 20-51; KRÁL, Pavel: Das Aussterben böhmischer Adelsgeschlechter an der Wende vom 16. zum 17. Jahrhundert. In: WREDE, Martin - CARL, Horst (Hg.): Zwischen Schande und Ehre. Erinnerungsbrücke und die Kontinuität des Hauses. Mainz 2007, s. 387-398.

2 Udělování obyvatelského práva (inkolátu) se vůčihledně zintenzivnilo v době vlády Rudolfa II., kdy císařský dvůr sídlil v Praze, a české prostředí tak přitahovalo cizince z celé Evropy, především ovšem z rakouských a německých zemí. Podrobněji k tomuto právnímu institutu v předbělohorské epoše STARÝ, Marek: Cizozemci a spoluobyvatelé : Udělování českého obyvatelského práva (inkolátu) v době předbělohorské. Praha 2018, passim, kde je též přehled starší literatury.
} 
55 rytířských osob. ${ }^{3}$ Je ovšem nutno konstatovat, že jejich publikovaný seznam není zřejmě možné považovat za úplný, nebot' v důsledku selhání lidského faktoru došlo patrně i k dalším přijímacím aktům, jež ale nebyly deskami řádně zachyceny.

Za př́klad si lze vzít sněm v roce 1603 . V jeho průběhu bylo 16 . ledna do relačního kvaternu zemských desek intabulováno přijetí bratranců Jáchyma a Víta Viléma Španovských z Lisova, ${ }^{4}$ teprve v roce 1607 pak bylo v rámci mnoha dalších obdobných aktů zapsáno též přijetí Kryštofa Haranta z Polžic, k němuž ale nepochybně došlo právě již $\mathrm{v}$ roce $1603 .{ }^{5}$ Zápisky jednoho $\mathrm{z}$ významných aktérů politického života té doby, Viléma Slavaty z Chlumu a Košumberka, hovoři ovšem při popisu sněmovních jednání ke dni 16. ledna 1603 o tom, že před shromážděné příslušníky panského stavu předstoupili pan Krištof Harant, JMCské komorník, pan Joachym, pan Hons Vít a pan Vilím strejcové Španovští a pan N. Dageczký, dadouce nám prímluvní psaní od JMCské a požádali, aby jim páni dovolili vstoupit do jejich řad, o čemž bylo následně rozhodnuto kladně. ${ }^{6}$ Bude-li pominuta skutečnost, že Slavata poněkud popletl jména příslušníků rodu Španovských (dochovaná císařská prrímluva z 8. ledna hovoří o Jáchymovi mladším, Ferdinandovi a Vítu Vilémovi), ${ }^{7}$ vyplývá z jeho memoárů dosti patrně, že společně s nimi a Kryštofem Harantem byl do panského stavu přijat ještě jeden šlechtic. ${ }^{8}$

Již Antonín Rezek při vydání Slavatových Zápisků v poznámce pod čarou poznamenal, že příslušná pasáž textu není přiliš dobře dochovaná a jím uváděný tvar rodového jména Dageczký by též mohl být čten jako Rageczky. Tímto marginálním dovětkem se dostal

\footnotetext{
3 Podrobně k tomu TÝŽ: Rytíři přijatí do českého panského stavu v době předbělohorské. Sborník archivních prací 60, 2010, č. 1, s. 240-278. Obdobný proces přijímání do stavu rytířského zpracoval zevrubně a ve srovnávací perspektivě KLECANDA, Vladimír: Přijímání do rytířského stavu v zemích českých a rakouských na počátku novověku (Příspěvek k dějinám nižší šlechty). Časopis Archivní školy VI, 1928, s. 1-125.
}

4 Dvě samostatné relace lze nalézt in: Národní archiv (dále NA) Praha, fond Desky zemské, Desky zemské stavovské (dále DZSt) 51, fol. A10v-A11r (Jáchym), resp. A 11v-A 12r (Vít Vilém); editovány jsou v Sněmy české od léta 1526 až po naši dobu (dále SČ), díl X., Praha 1900, s. 434, č. 327 a 328.

5 DZSt 52, fol. B 17v-B 18v, editováno in: SČ, díl X., s. 435, č. 329. Také tuto prodlevu s intabulací Kryštofova přiznání lze chápat jako projev (posléze napraveného) pochybení administrativního aparátu úřadu desek zemských.

$6 \quad$ REZEK, Antonín (ed.): Zápisky Viléma Slavaty z let 1601-1603 : Rozpravy tř́dy pro filosofii, dějepis a filologii královské české společnosti náuk z roku 1887-1888, řada VII, svazek 2. Praha 1888, s. 58.

$7 \quad$ NA Praha, fond Stará manipulace (dále SM), sign. S 209/S 287, inv. č. 3343, kart. 2310; fond Královská registra (dále RG), č. 111, fol. 5r-5v, č. 11. Císařská přímluva je v registrech nadepsaná Stavu panskému do sněmu vČechách o prijetí do stavu jich bratř́ Španovských, což je nepochybně důvod, proč August Sedláček v hesle věnovaném Španovským (Ottův slovník naučný, díl XXIV. Praha 1906, s. 742), prohlásil všechny tři za syny Erasma Španovského z Lisova († 1585), jenž seděl na Walterskirchenu v Rakousku. Podle něj sestavil genealogii Španovských také PROCHÁZKA, Roman: Genealogisches Handbuch erloschener böhmischer Herrenstandsfamilien. Neustadt an der Aisch 1973, s. 353-354. Avšak skutečnost, že Jáchym mladší je v listu uveden sezením na Vožici a Še[l] mberce jasně ukazuje, že šlo o jednoho z mladších synů někdejšího nejvyššího zemského písaře Michala Španovského z Lisova († 1599/1600). Neodporuje tomu ve skutečnosti ani samotný text prímluvy, v níž jsou jako adresáti uvedeni Joachym mladší Španovský z Lisova na Vožici a Šemberce, Ferdinand a Vít Vilím, bratři vlastní Španovští odtudž z Lisova, v[ěrní] N[aši] milí. Zde se totiž výraz bratři zcela nepochybně vztahuje na posledně dva jmenované, zatímco Jáchyma může, ale nemusí zahrnovat. Jako Michalův syn je Jáchym zachycen také v rodokmenu in: NA Praha, fond Genealogická sbírka Dobřenský, inv. č. 1077, kde je u Ferdinanda a Víta Viléma poznámka, že získali v lednu 1603 panský stav. V případě Ferdinanda je to ale sporné, nebot přímluva se sice dochovala, ale relace o jeho přijetí není v zemských deskách zachycena.

$8 \quad$ V tomto směru je velmi pozoruhodné, že Adam mladší z Valdštejna, další významný aristokrat, který si ve sledovaném období vedl deníkové záznamy, se o tomto dalším šlechtici nezmínil. KOLDINSKÁ, Marie - MAŤA, Petr (eds.): Deník rudolfinského dvořana : Adam mladší z Valdštejna 1602-1633. Praha 1997, s. 59 (16. ledna - A dnes jest prijat pan Harant za pána a páni Španovštî). 
na správnou stopu vedoucí k moravskému rytířskému rodu Rájeckých z Mírova. ${ }^{9}$ Jeho předek Heralt z Kochtic byl v 70. letech 14. století purkrabím olomouckého biskupa na hradě Mírově, který později získal do držby, stejně jako lenní statek Rájec, od něhož si rodina vzala př́jmení. Ten Heraltovi potomci drželi do roku 1554, kdy Zikmund Rájecký z Mírova společně s bratrem Markvartem potvrdil vsi Rájec odúmrtní právo, vzápětí ji ale prodal Žerotínům. ${ }^{10}$ Kromě toho se ve druhé polovině 15 . století od Rájeckých oddělila linie Váleckých z Mírova, která vymřela v roce $1589 .{ }^{11}$ Na počátku 17. století byl již naživu jediný, poslední příslušník tohoto rozrodu - Jan Rájecký z Mírova, syn Markvarta Rájeckého († 1589) a Bohunky Bítovské z Lichtenburka († 1590). ${ }^{12}$ Ten nabyl zletilosti právě $\mathrm{v}$ roce $1590^{13}$ a statek Osová, který po matce zdědil, prodal obratem i jménem nezletilé sestry Elišky svému dosavadnímu poručníkovi, Smilovi Osovskému z Doubravice a na Třebíči za 15000 zlatých. ${ }^{14}$

O tom, že se Slavatův záznam z roku 1603 týká právě Jana Rájeckého z Mírova, nemůže být nejmenších pochyb. Vyplývá to již z kontextu, především to ale dosvědčuje přímluva císaře Rudolfa II., datovaná 10. ledna 1603 a adresovaná zástupcům panského stavu shromážděným na zemském sněmu. Její koncept je zachován ve fondu Stará manipulace. ${ }^{15}$ Je na něm sice kancelářská poznámka Nevyšlo, avšak totožný text se nachází v královských registrech, v knize, do níž byly zapisovány texty odesílaných otevřených listů (misivů). ${ }^{16}$ Což nasvědčuje spíše tomu, že vyhotovení a odeslání čistopisu nakonec přeci jen proběhlo. Ostatně bez královské přímluvy by panský stav patrně Rájeckého žádost na sněmu vůbec nebyl projednal.

9 Základní informace o tomto rodu shromáždili August Sedláček in: Ottův slovník naučný, díl XXI. Praha 1904, s. 71-72, a PILNÁČEK, Josef: Staromoravští rodové. Vídeň 1930, s. 467-468, č. 2015. Mohli přitom vycházet z PAPROCKÝ z Hlohol a Paprocké Vůle, Bartoloměj: Zrdcadlo slavného markrabství moravského. Olomutii 1593, s. CCCXLI-CCCXLII.

10 HOSÁK, Ladislav: Historický místopis země Moravskoslezské. Praha 1938, s. 567.

11 PILNÁČEK, J.: Staromoravští rodové, s. 467-468, č. 2015.

12 Přesná data úmrtí - 24. června 1589, resp. 24. ledna 1590 - uvedl na základě nedochovaných náhrobníků obou manželů v kostele v Malé Býteši (dnes Osová Bitýška) PAPROCKÝ, B.: Zrdcadlo, s. CCCXLII.

13 Dosvědčuje to skutečnost, že berní přiznání za svatomikulášský a Vánoční termín za rok 1589 vykonal jménem Smila Osovského z Doubravice, poručníka sirotků po Markvartovi a Bohunce, Jan Hoštický z Hoštic, správce statku Osová. RADIMSKÝ, Jiří: A 7 - Přiznávací berní listy 1528-1623. Katalog. Archivní pomůcka. Brno 1961, s. 163, č. 94, s. 169, č. 233, s. 176, č. 143.

14 ROHLÍK, Miloslav (ed.): Moravské zemské desky III. 1567-1641. Kraj brněnský (dále MZD III BR). Praha 1957, kniha XXXI (XXVII), s. 193-195, č. 34. Prodej Osové je poslední epizoda rodové historie, kterou zachytili KADICH, Heinrich von - BLAŽEK, Conrad: Der mährische Adel. J. Siebmacher's grosses und allgemeines Wappenbuch, Band IV, Abtheilung 10. Nürnberg 1899, s. 108.

15 SM, sign. S 209/R 17, inv. č. 3342, kart. 2304 (Rudolf. Vysoce urozený, urození, v[ěrní] N[aši] $m$ [ilí]. Tejna vás činiti neráčíme, že sme z mocnosti Naši císařské a jakožto král český a markrabě moravský urozeného Jana Rájeckýho $z$ Mírova na Pernštejně, $v$ [ěrného] $N$ [ašeho] $m$ [ilého], v témž markrabství moravském i také ve vší Římské řiši pro služby předkův jeho předkuom Našim činěné, tolikéž pro vlastní jeho Nám kobzvláštnímu zalíbení prokázané zásluhy, za pána vyhlásiti a jemu majestát Náš dáti ráčili. I vznesl jest na Nás dotčený Jan Rájecký, že toho oumyslu jest, toho prí vás a stavu vašem, aby v tomto králov[ství] českém za pána príiat, jmín a držán byl, náležitě hledati. Nás $k$ vám za milostiv[o] u prímluvu poníženě prosíce. Kderéž nemohouce jemu odepríti, $k$ vám se primlouvati a milostivě žádati ráčíme, když toho pak prí stavu vašem vyhledávati bude, že jej prí nynějším tomto sněmu mezi sebe a do stavu vašeho panského podle svobod vašich a dobrého porádku prïimete a této Naši prímluvy užíti dáte. A My vám to etc. Dán na $h$ [radě] $N$ [ašem] $p$ [ražském] v pátek po svatých třech králích léta etc. [1]603.). Adresa: Stavu panskému do Čech.

16 RG 111, fol. 9v-10r, č. 19 (nadepsáno Stavu panské[m]u do Čech o príietí do stavu jich Jana Rájeckýho). Již výše byla zmíněna další přímluva za Španovské z Lisova, a tak se sluší pro úplnost doplnit, že 8 . ledna vystavila dvorská kancelář také přímluvu za Kryštova Haranta z Polžic. Tamtéž, fol. 6r-6v, č. 13. 
V Rudolfově přímluvném listu se hovoří o tom, že panovník udělil Rájeckému na panský stav majestát. K tomu je třeba dodat, že z právního hlediska šlo o krok svým způsobem nadbytečný - z hlediska možnosti vstupu mezi vyšší šlechtu hrálo klíčovou úlohu rozhodnutí samotného stavu a od císaře se očekávala především formalizovaná přímluva. Tím se přijímání do panského stavu na první pohled odlišovalo od přijímání do stavu rytířského, kde kandidáti skutečně museli předkládat panovnický erbovní list (Wappenbrief, př́padně - pokud šlo o dokument vydaný kanceláŕí ř́šsskou - Adelsbrief). ${ }^{17}$ Více se tedy naopak přibližovalo právní a administrativní praxi, známé z předbělohorského udělování českého obyvatelského práva (inkolátu).

Skutečnost, že slavnostní panovnické listy na panský stav neměly v Čechách patřičnou odezvu, se velmi nápadně odráží v nevelkém množství těchto aktů, které v předbělohorské době do českého šlechtického prostředí směřovaly. Zatímco erbovní listy vycházely z české dvorské kanceláře tak rríkajíc ve velkém a patřily mezi poměrně obvyklé typy pragmatických písemností, listy přiznávající adresátům status pánů jsou v kontrastu s tím $\mathrm{v}$ české kancelářské praxi velmi výjimečné. Ve větší (ovšem nikterak masové) míře se začaly objevovat právě až na přelomu 16. a 17. století, přičemž ale jejich adresáty byli bez výjimky rytíři moravští. K tomu je možno doplnit, že v několika případech byli šlechtici ze zemí České koruny obdařeni majestáty provenienčně říšskými, jimiž jim byl udělen stav svobodných pánů (Freiherrenstand).$^{18}$

Pokud jde o Jana Rájeckého, datum jeho povýšení na pána, 10. dubna 1602, bylo známo již Augustu Sedláčkovi, který ho uvedl v krátkém hesle věnovaném rodu Rájeckých

\footnotetext{
17 Zatímco v českém prostředí byly vydávány výhradně erbovní listy, udělující erb a zpravidla i predikát, nic ovšem neměnící na stavovském zařazení adresáta mezi (nyní již tzv. erbovní) měštany, říšská administrativní praxe rozlišovala mezi pouhým udělením erbu na jedné a udělením erbu a šlechtictví na druhé straně. Vývoj říšské nobilitační praxe zmapoval zřejmě nejzdařileji FRÖLICHSTHAL, Georg: Nobilitierungen im Heilichen Römischen Reich. In: ELVERFELDT-ULM, Sigismund (Hg.): Adelsrecht : Entstehung - Struktur - Bedeutung in der Moderne des historischen Adel sund seiner Nachkommen. Limburg an der Lahn 2001, s. 67-119, další zásadní texty věnované především udělování titulů ze strany Habsburků do 18. století publikoval PFEIFER, Gustav: Wappenbriefe. In: PAUSER, Josef - SCHEUTZ, Martin - WINKELBAUER, Thomas (Hg.): Quellenkunde der Habsburgermonarchie (16.-18. Jahrhundert) : Ein exemplarisches Handbuch. Wien - München 2004, s. 291-302; TÝŽ: Wappenbriefe. In: PARAVICINI, Werner - HIRSCHBIEGEL, Jan - WETTLAUFER, Jörg (Hg.): Höfe und Residenzen im spätmittelalterlichen Reich: Hof und Schrift. Ostfildern 2007, s. 645-672. Z českých prací jsou pro dobu předbělohorskou zásadní zejména FIALA, Michal: Tři studie k české renesanční heraldice (Znaky měštanů Starého Města pražského v letech 1526-1618 ve světle salbuchů). Heraldická ročenka 20, 1983, s. 3-32; Totéž, Heraldická ročenka 21, 1984, s. 3-87; KREJČÍK, Tomáš: Erbovní listiny jako specifický druh historického pramene. In: FIALA, Michal - KREJČÍK, Tomáš (eds.): Erbovní listiny Archivu Národního muzea. Praha 2001, s. 7-38; TÝŽ: Diplomatika erbovních listin vydaných českou panovnickou kanceláří ve 14.-18. století. In: ŠIŠMIŠ, Milan (ed.): Erbové listiny : Patents of Arms. Martin 2006, s. 132-144; TÝŽ: Nové poznatky o vývoji erbovních a nobilitačních listin. In: BRŇOVJÁK, Jiří - FIALA, Michal (eds.): Litterae armorum : Erbovní listiny Národního archivu v Praze. Ostrava - Praha 2011, s. 11-72; a naposledy BRŇOVJÁK, Jiří: Šlechticem z moci úřední : Udělování šlechtických titulů v českých zemích 1705-1780. Ostrava 2018, s. 52-56 (zde je také v poznámkovém aparátu na s. 8-15 bohatá komentovaná bibliografie prací, které se k nobilitacím a souvisejícím otázkám vztahují, včetně řady soupisů a edicí těchto dokumentů).
}

18 Z českých nižších šlechticů obdrželi, nakolik je známo, podobné „povyšovací“ listy pouze místokancléř Kryštof Želinský ze Sebuzína (1596), bratři Jindřich Michael a Bernart Hýzrlové z Chodů (1611) a Vilém, Zdeněk, Hertvík, Jan Zdeněk a Jiří Vratislavové z Mitrovic (1619). V poněkud větší míře směřovaly obdobné říšské majestáty do oblasti slezských knížectví. Srovnej k této problematice naposledy STARÝ, Marek: Majestáty na panský stav a jejich význam z pohledu české stavovské společnosti doby předbělohorské. Historica. Revue pro historii a př́buzné vědy 9, 2018, č. 2, s. 121-134; TÝŽ: Royal and Imperial Charters and the Acquisition of Bohemian Lordship (Herrenstand) in the Period before the Battle of White Mountain. In: BRŇOVJÁK, Jiři - ŽUPANIČ, Jan (eds.): Changes of the Noble Society. Aristocracy and New Nobility in the Habsburg Monarchy and Central Europe from the $16^{\text {th }}$ to the $20^{\text {th }}$ Century. Ostrava - Prague 2018, s. 19-35. 
v Ottově slovníku naučném. ${ }^{19} \mathrm{~V}$ české historiografii není možno dobrat se dalších, bližších informací o Janově povýšení. Originál panovnického majestátu se do dnešního dne zřejmě nezachoval. Přesto ale existuje řada písemností, z nichž lze další, hlubší poznání čerpat.

Na místě prvním si zmínku zaslouží složka věnovaná Rájeckého povýšení, uložená ve vídeňském Adelsarchivu. ${ }^{20} \mathrm{~V}$ ní se nachází pětice zásadních písemností. Především je to koncept samotného majestátu, nesoucí skutečně datum 10. dubna 1602 (fol. 2r-4v, 9r), dále originál listu Rudolfa II. arciknížeti Matyášovi ze 16. června 1602, zpravující adresáta o Janově povýšení (fol. $5 \mathrm{r}-5 \mathrm{v}$ ), koncept německy psaného nařízení dolnorakouské vládě z 8. července 1602, aby bylo Janovo povýšení náležitě publikováno (fol. $6 \mathrm{r}-6 \mathrm{v}$, in simili mělo být psáno též dvorské komoře a dvorské válečné radě), koncept listu nejvyššímu kancléři Království českého o Janově povýšení s datem 13. června 1602 (8r-8v) a konečně opis výše již zmíněné císařské přímluvy panskému stavu Království českého z 10. ledna 1603, aby Jana přijal do svých řad (10r-10v). Zatímco poslední uvedená písemnost je česká a jedná se podle připojené poznámky o opis z královských register, pořízený v roce 1845 , všechny zbylé materiály jsou dobové a jsou psány německy.

Všechny písemnosti dokumentují nějakým způsobem dobovou administrativní a kancelářskou praxi a dokreslují Rájeckého vzestup, klíčové je ovšem v první řadě samo císařské privilegium, jímž byl Jan za svobodného pána prohlášen. S tímto privilegiem se lze ale seznámit i ve fondech českých archivů, a to dokonce v českých překladech. První z nich se nachází ve šlechtických aktech v Moravském zemském archivu v Brně. ${ }^{21}$ Vedle toho lze pak na reflexi Janova povýšení na pána narazit ještě v jednom, na první pohled dosti nečekaném prameni. Jde o právní knihu (Manuál právnî) města Polné, ${ }^{22}$ kterou v roce 1584 založil tamní písař (notárius) Václav Hanzlík (Hanzlicides), původem z Havlíčkova Brodu. ${ }^{23}$ Tato kniha, obsahující vedle četných rozsudků soudů v Polné i v jiných českých městech také jakýsi výkladový slovník právních pojmů, je dnes uložena v Archivu Národního muzea. Úryvky z ní byly publikovány v roce 1940 ve sborníku Polensko, ${ }^{24}$ celkově ale zůstává nevytěženým zdrojem právněhistorického poznání raně novověkého městského práva. Prakticky na samém jejím konci, na foliu 291v (podle původního číslování 199v) začíná uprostřed stránky, hned za nálezem soudu Menšího Města pražského a jeho nápravou („reformací“) ze strany apelačního soudu a následnou revizí ze strany císaře Rudolfa II., text Rudolfova majestátu pro Jana Rájeckého z Mírova. Za ním již následuje pouze poslední rozhodnutí hraničního soudu z roku 1603, další folia jsou již prázdná. Text majestátu je ovšem již na první pohled nekompletní - končí dispozicí a nezahrnuje

19 Ottův slovník naučný, díl XXI, s. 71-72. Nově toto datum zopakoval např. ŠTARHA, Ivan: Za nových vrchností. In: Doubravník v dějinách 1208-2008. Doubravník 2008, s. 143.

20 Österreichisches Staatsarchiv Wien, Allgemeines Verwaltungsarchiv, Adelsarchiv, Reichsadelsakten, Allgemeine Reihe, sign. 332.64.

21 Moravský zemský archiv (dále MZA) Brno, fond A 12 - Akta šlechtická, kart. LVIII, sign. 13/2. Součástí opisu je i kancelářská poznámka Ad mandatum sacrae Caes[ar]ae M[ajesta]tis proprium a podpis ř́šského místokancléře Jana Barvicia, což jsou další nezpochybnitelné důkazy toho, že listina vyšla z ř́išské kanceláre.

22 Archiv Národního muzea Praha, fond Sbírka rukopisů, č. 957.

23 Jeho stručný medailon viz HLADÍK, Bohumil: Významné polenské osobnosti a rodáci, In: Polná 1242-1992. Polná 1992, s. 199.

24 HANZLICIDES, Václav: Zápisy městského práva polenského. Polensko. Kulturně-historický a vlastivědný sborník 3, 1940, č. 1, s. 1-4; Tamtéž, č. 2, s. 16-18; Tamtéž, č. 3, s. 24-25; Tamtéž, č. 4, s. 39-42; Tamtéž, č. 5, s. 47-52; Tamtéž, č. 6 , s. 65-69. 
sankci, koroboraci ani dataci, tím méně pak podpis vydavatele a další podpisy, jimiž byly kancelářské písemnosti standardně opatřovány.

Vzhledem k tomu, že jsou oba dochované české texty prakticky totožné, ${ }^{25}$ zdá se pravděpodobné, že vycházely ze společné předlohy. Popř́padě lze uvažovat o tom, že neověřený a podle písma zcela zjevně dobový opis v Aktech šlechtických (okolnosti jeho vzniku nejsou bohužel žádným způsobem patrné) posloužil jako předloha pro neúplný text Hanzlíkův. Každopádně je ale pozoruhodné, že se jedná o texty české, nebot́ originál privilegia z říšské kanceláře byl nepochybně vydán německy, jak o tom svědčí i dochovaný koncept. Opět se lze pouze dohadovat, proč došlo k pořízení českého překladu. Nabízí se hypotéza, že mohl být předložen panskému stavu v Čechách či na Moravě v souvislosti s Janovým úsilím o společenský vzestup mezi vyšší šlechtu, k němuž - jak již bylo výše uvedeno - císařské privilegium nepostačovalo a bylo třeba souhlasu samotných pánů. Každopádně se ale tento překlad jeví být písemností poměrně ojedinělou a zároveň dosti zajímavou, a to i z jazykového hlediska. Proto je připojen v závěru této studie paralelně s originálním textem německým.

$\mathrm{Z}$ textu majestátu lze mimo jiné vyvodit dvě důležité skutečnosti, komplementárně doložitelné dalšími archivními prameny. Tu první lze nalézt v naraci, z níž jednoznačně vyplývá, že pokud císařské povýšení oceňovalo zásluhy samotného Jana Rájeckého, odehrály se tyto především, ba spíše výhradně na poli válečném. A to na uherských bojištích, kde se habsburské válečné síly se střídavým úspěchem střetávaly s hrozným nepřitelem všeho křestanstva, armádami turecké Osmanské říše. Jan v této válce zastával „přední vojenské ouřady“ a měl také na starost zajištování přísunu nových oddílů, o čemž svědčí mimo jiné císařùv list z 10. června 1602, jímž mu bylo nakázáno, aby mustroval nikoli v Tišnově, ale v městečku Vejmyslice (dnes Vémyslice). Zajímavé je, že ačkoliv list byl vydán později než privilegium nobilitační, přesto je v něm Jan osloven Slovutný věrný Náš milý, což byla titulatura př́islušející příslušníkům stavu rytířského. ${ }^{26}$ Další dokument z 1. července pak dokládá, že Rájecký byl společně s dalším šlechticem (zřejmě Volfem Jiřím Mengersreiterem z Truchlova) pověřen odvést do Uher 1000 arkebuzírských rejtarů. ${ }^{27}$ Jiný list vydaný císařem několik let po Janově smrti ho pak označuje jako nejvyžšího na onen čas nad 500 knechty v království uherském..$^{28}$ Janovo zaměření na vojenskou službu ostatně vhodně dokumentuje také Paprockého zpráva, že v době sepisování díla Jan v vlaských krajinách v věcech rytírských se obírá. ${ }^{29}$

Druhá důležitá informace, kterou v sobě císařský majestát nese, spočívá v tom, že mimo jakoukoliv pochybnost dokládá Rájeckého držbu hradu a panství Pernštejn. Velké části dosavadních prací mapujících osudy tohoto významného panského sídla a jeho dominia, totiž jeho držba unikla. A to zejména z toho důvodu, že se nepromítla do zemských desek. Ty dokládají, že na sklonku 16. století byl Pernštejn majetkem Pavla Katarýna z Kataru,

\footnotetext{
25 Objevuje se toliko několik zcela marginálních rozdílů, např́iklad v psaní koncovek přídavných jmen ve tvaru -ý nebo -ej. I v tomto ohledu je ale v drtivé většině př́ípadů mezi oběma texty shoda.

26 RG 110, fol. 178v. List je zmíněn i v LÍVA, Václav (ed.): Regesta fondu Militare Archivu ministerstva vnitra Rčs. v Praze, Díl II: 1590-1617. Praha 1938, s. 230.

27 Tamtéž, s. 232. Arkebuzířští rejtaři představovali zvláštní druh lehkého jezdectva, jehož výzbroji dominovala krátká ručnice (arkebuza).

28 NA Praha, fond Morava, inv. č. 5643. Za číslovkou 500 začal písař psát „Ar“ (zjevně arkebuzíry), avšak poté tato písmena škrtnul a dal přednost použití termínu knechty.

29 PAPROCKÝ, B.: Zrdcadlo, s. CCCXLII.
} 
místodržícího nejvyššího písařství a zemského purkrabího, jenž v roce 1599 zapsal své choti Kateřině Jankovské z Vlašimi 4000 zlatých (1250 věna a 2750 nadvěna) na statku Jimramov, který byl s Pernštejnem vlastnicky spojen. Na částku nadvěna ho pak jeho chot' přijala na spolek. ${ }^{30} \mathrm{O}$ deset let později, v roce 1609 , byla potom do zemských desek vložena smlouva (datovaná 20. ledna téhož roku), jíž Pavlovi synové Petr a Jan Katarýnové prodali pernštejnské zboží Adamovi Lvovi Lickovi z Rýzmburku a jeho choti Esteře Zejdlicové ze Šenfeldu za 31000 zlatých. ${ }^{31}$ Každý z manželů se tak stal majitelem jedné poloviny statku, přičemž o několik let později se s těmito polovinami vzájemně spolčili. ${ }^{32}$ Př́tomnost Adama Lva Licka z Rýzmburka a na Pernštejně mezi pečetiteli landfrýdu z 3. září 1608, vloženého v roce 1609 do olomouckých zemských desek, ${ }^{33}$ sice signalizuje, že ve skutečnosti vyšel Pernštejn $z$ držby Katarýnů poněkud dříve, posloupnost držitelů ale žádným způsobem nezpochybňuje. Ve své moravské historické topografii ji prezentoval také Ladislav Hosák, jenž položil koupi statku manželi Lickovými do roku 1604. ${ }^{34}$ Jeho interpretace rezonuje i řadou dalších textů, které se dějin pernštejnského panství v inkriminovaném období dotýkají. Pro pořádek se ale sluší upozornit, že nejnovější, kritická historiografická díla již držbu Rájeckého dokázala reflektovat. ${ }^{35}$

O Janu Rájeckém bylo již výše řečeno, že jménem svým i sestry Elišky prodal v roce 1590 zděděný statek Osová. Na nějakou dobu se tak stal šlechtickým bezzemkem, což ovšem vzhledem $\mathrm{k}$ jeho nasměrování na vojenskou kariéru nepředstavovalo zásadní existenční problém. Na přelomu 16. a 17. století (konkrétně v letech 1599 a 1600) se v moravských berních rejstřících objevuje jako pán nevelkého jihomoravského statku Našiměřice. ${ }^{36}$ Jakým způsobem ho nabyl a jaký byl jeho rozsah, to jsou otázky otevřené dalšímu, podrobnějšímu výzkumu. Jisto je, že představoval značně skromné ekonomické zázemí. Navíc jeho součástí nebyl odpovídající objekt rezidenčního charakteru, nebot' původní stř̌edověká našiměřická tvrz zanikla již v průběhu 15. století. ${ }^{37}$ Velmi podobně lze charakterizovat také zboží Dyjákovičky, které se na počátku 17. století stalo novým Janovým majetkem. ${ }^{38}$

$\mathrm{Z}$ tohoto pohledu představoval Janův zájem o Pernštejn posun do naprosto neporovnatelných mocensko-ekonomických souřadnic. Ve světle pramenů je ovšem nezpochybnitelný, přičemž „korunou důkazů“ je v tomto případě kupní smlouva, jíž Jan uzavřel s poručníky mladých Katarýnů dne 9. května 1602 a v níž se zavázal zaplatit za pernštejnské zboží s hradem, pivovarem, sladovnou, pustým dvorem, mlýnem, pilou a dalším

\footnotetext{
$30 \quad$ MZD III BR, kniha XXXIII (XXIX), s. 319, č. 15 a 16.

31 MZD III BR, kniha XXIV (XXX), s. 374-375, č. 15. Na základě tohoto zápisu kladl prodej Pernštejna do roku 1609 v jinak velmi zdařilé studii věnované rodu Katarýnů HONC, Jaroslav: Falešný moravský rytíř pan Pavel Katarýn z Kataru a Rubinsteina a konfrontace české kanceláře v Praze a moravských stavů 1588-1613. Listy Genealogické a heraldické společnosti v Praze, Řada 5, červen 1977, s. 81.
}

32 MZD III BR, kniha XXXIV (XXX), s. 434-435, č. 100-101.

33 MATĚJEK, František (ed.): Moravské zemské desky III : 1567-1642. Kraj olomoucký. Praha 1953, kniha XXXIII, s. 410-413, č. 5 .

34 HOSÁK, L.: Historický místopis, s. 331.

35 ŠTARHA, I.: Za nových vrchností, s. 143, a zejm. VAŠEK, Leoš - KONEČNÝ, Michal: Kryštof Pavel z Liechtensteinu-Castelkornu a Morava v časech třicetileté války. In: KONEČNÝ, Michal (ed.): Kryštof Pavel z Liechtensteinu-Castelkornu a Morava v časech třicetileté války. Brno 2010, s. 11.

36 RADIMSKÝ, J.: A 7 - Přiznávací berní listy 1528-1623, s. 420, č. 140; Tamtéž, s. 463, č. 79.

37 PLAČEK, Miroslav: Ilustrovaná encyklopedie moravských hradů, hrádků a tvrzí. Praha 2001, s. 426-427.

38

Sezením na Malých Dyákovicích se píše v níže citované smlouvě o koupi Pernštejna, uzavřené 9. května 1602. 
příslušenstvím, městečkem Doubravník, městečkem Nedvědice s panským domem, pivovarem, sladovnou a chmelnicí, městečkem Štěpánov, 39 jmenovitě uvedenými vesnicemi ${ }^{39}$ a dalším příslušenstvím částku 31000 zlatých. $Z$ toho 20000 měl položit hotově při předání statku (mělo k němu dojít 29. května), zbytek měl splatit postupně, resp. měl uhradit některé dluhy po Pavlu Katarýnovi. ${ }^{40}$

I když hrál při zisku pernštejnského zboží dozajista významnou roli úvěr, je jasně patrné, že se Janovi Rájeckému podařilo nashromáždit nezanedbatelné prostředky vojenskou službou. Další faktor jeho náhlého a velmi zjevného vzestupu je zřejmě třeba hledat také v jeho sňatku s Ester Zejdlicovou ze Šenfeldu, jednou z dcer českého podkomořího a vrchního hejtmana všech císařských panství v Království českém, Hertvíka Zejdlice ze Šenfeldu († 1603). ${ }^{41}$ Tento mimořádně schopný rytíř dosáhl v roce 1588 přijetí do českého panského $\operatorname{stavu}^{42}$ a podařilo se mu shromáždit úctyhodný majetek. Velmi výmluvně o tom vypovídá testament, který Hertvík sepsal 26. února 1602 v Praze. ${ }^{43}$ Jako hlavní dědici v něm byli v souladu s dobovými zvyklostmi označeni synové Jan, Rudolf a Jindřich, pokračovatelé rodu a nositelé rodového jména a erbu, poměrně velkoryse ale byly zaopatřeny i dcery (Ester, Bohunka, Eliška, Anna a Marie). Po prodeji panství Zvoleněves a Horoměřice, k němuž Hertvík své syny nabádal, měla každá z nich obdržet 5000 kop míšeňských grošů, které měly být zapůjčeny na obvyklý úrok a hlavní suma pak měla představovat jejich věno. Vedle toho jim bratři měli na svůj náklad vystrojit odpovídající svatební veselí. Pouze na nejstarší Hertvíkovu dceru Johanku se toto ustanovení testamentu nevztahovalo, nebot tu náležitě „vybyl“ sám otec, když ji už předtím provdal za Viléma Dobříkovského z Malejova.

Nakonec se ale Hertvík, jehož smrt zastihla 20. ledna $1603,{ }^{44}$ stihl postarat i o druhorozenou Ester, k jejímuž sňatku došlo zřejmě ještě v roce 1602, patrně v relativně úzkém intervalu mezi 26. únorem, kdy se v otcově závěti uvádí jako svobodná, a 9. květnem, kdy

\footnotetext{
39 Křižovice, Křeptov, Maňová, Husle, Klokočí, Rakové, Klečany, Černvír, Chlébské, Skorotice, Smrček, Věžná, Býšovec, Litava, (Pernštejnské) Jestřabí, Sejřek, Jámy, Bor, Borovec, Čtyři Dvory, Lesoňovice, Koroužné, Švařec, Vrtěžír, Nivy, Kozlov (Rychta kozlovská), Pivonice, Hrdá Ves, Horní Čepí, Dolní Čepí, Ujčov, Kovářová, Lískovec, Olešnička, Černovice, Hodonín, Stř́itež, Zlatkov, Janovičky.

40 Originál smlouvy se nachází v MZA Brno, fond G 147 - Rodinný archiv Mitrovských Dolní Rožínka, i.č. 122, kart. 33. Na existenci smlouvy upozornili VAŠEK, L. - KONEČNÝ, M.: Kryštof, s. 11. Ačkoliv smlouva předpokládala, že obě její strany „mají a povinni budou... při nejprvnějším soudu zemském, kterýžv městě Brně držán bude, před jich milost nejvyšši pány ouředníky a soudce zemské předstoupiti a za vložení jí do desk zemských žádati i také od vkladu společně zaplatiti, k tomuto kroku již nedošlo. Přitom se podzimní, svatokunhutské brněnské zasedání zemského soudu řádně konalo - viz MZD III BR, kniha XXXIII (XXIX), s. 341-344, č. 47-50; BRANDL, Vincenc (ed.): Spisy Karla Staršího z Žerotína. Oddělení I. Žerotínovi zápisové o soudě panském, 1, Brno 1866, s. 174-192. Podstatné náležitosti smlouvy jsou obsaženy v deskovém vkladu z roku 1609 - viz níže.

41 Základní biografické údaje o Hertvíkovi soustředil již August Sedláček v hesle Zejdlic ze Senfeldu in: Ottův slovník naučný, díl XXVII., s. 525. Dále k jeho osobě např. NOVOTNÝ, David: „Jedouce do Moravy“ aneb Hertvík Zejdlic ze Šenfeldu a na Polné jako hospodář, soused a podkomoří věnných měst. Vlastivědný sborník Vysočiny. Oddíl věd společenských 16, 2008, s. 19-33; STARÝ, Marek: Přední klenot zemský : Větší zemský soud království českého v době rudolfinské. Praha 2014, s. 205-206, 212-213.

42 Deskový zápis o jeho přijetí do panského stavu nese datum 23. února 1588 - viz DZSt 47, fol. L 17v-L 18r. Edice zápisu je v GINDELY, Anton - DVORSKÝ, František - PAŽOUT, Julius (eds.): Sněmy české od léta 1526 až po naši dobu, VII: 1586-1591. Praha 1891, s. 273, č. 160. Viz také STARÝ, M.: Rytírí, s. 260-261.

43 NA Praha, fond Desky zemské, sign. Desky zemské větší (dále DZV) 131, fol. K 14v-K 19v.

44 Datum Hertvíkovy smrti potvrzuje několik nezávislých dobových pramenů, edičně zpř́istupněných - viz PILAT, Kaspar: Materialen zur diplomatischen Genealogie des Adels der österreichischen Monarchie, I. Prag 1812, s. 153; NOVÁČEK, Vojtěch Jaromír: Drobné zprávy historické. Památky archaeologické a místopisné 16, 1893, č. 1, s. 47-52, s. 51; KOLDINSKÁ, M. - MAŤA, P. (eds.) Deník, s. 60.
} 
byla uzavřena kupní smlouva na pernštejnské panství. Výše uvedená částka 5000 kop, kterou Ester zřejmě jako věno skutečně obdržela, nebyla totiž ve vztahu k ceně pernštejnského panství (byt' v rámci rozprodeje katarýnských statků nepochybně podceněného) v žádném prrípadě zanedbatelná, a navíc lze předpokládat, že Jan mohl sehnat odpovídající úvěr právě díky čerstvému spř́iznění s bohatým a vlivným podkomořím (nelze vyloučit, že peníze do této transakce přímo vložil sám Zejdlic). Na překážku této hypotéze není skutečnost, že se Ester ve smlouvě jmenovitě neuvádí - raně novověká společnost byla výrazně maskulinní, a i když lze najít výjimky, obvykle přece jen obdobné kontrakty uzavírali pouze muži.

Mimochodem se sluší upozornit, že i Janův zájem o pernštejnské zboží a jeho prosazení se do role kupujícího (nebot' je nanejvýš pravděpodobné, že o statek bylo více zájemců, zvláště vzhledem k příznivé ceně) měly svůj původ v př́ibuzenských vazbách - jeho sestra Eliška se totiž provdala za Zikmunda Volfa Jankovského z Vlašimi († 1622), jednoho z poručníků sirotků po Pavlu Katarýnovi (mezi poručníky byl Zikmund Volf vybrán jakožto bratr druhé Pavlovy choti Kateřiny Jankovské). ${ }^{45}$ Pernštejnské zboží se tak prodávalo tak ř́íkajíc v rámci rodiny, byt mladí Katarýnové přímo pokrevně s Rájeckým spřízněni nebyli.

To, že prodej Pernštejna nebyl intabulován do moravských zemských desek, bylo nepochybně způsobeno především tím, že v té době probíhal soudní spor, v němž se královský prokurátor snažil zpochybnit příslušnost rodiny Katarýnů k rytířskému stavu, čímž by bylo v př́padě úspěchu žaloby negováno i jejich právo nabývat svobodných statků a klást je do desek. Obdobně, tedy bez deskového vkladu, proběhl ostatně i rozprodej dalších katarýnovských statků. ${ }^{46}$ Spíše za shodu okolností lze v tomto ohledu považovat skutečnost, že se nedlouho po prodeji uzavřela i životní dráha posledního mužského příslušníka rodu Rájeckých z Mírova.

August Sedláček v krátkém encyklopedickém hesle o Rájeckých z Mírova, otištěném v jednadvacátém díle Ottova slovníku naučného, datoval smrt Jana Rájeckého do roku 1610 a doplnil, že $s$ ním tato rodina vyhasla ${ }^{47}$ Stejné datum úmrtí je uvedeno také v genealogické sbírce Jana Václava hraběte Dobřenského v pražském Národním archivu. ${ }^{48} \mathrm{Ve}$ skutečnosti ale posledního Rájeckého zastihla smrt o poznání dříve. Jeho vdova se totiž podruhé provdala za českého pána Adama Lva Licka z Rýzmburka, a to již následujícího roku 1604. Ne snad, že by tento manželský pár toho roku společně koupil Pernštejn, jak mylně uvedl Ladislav Hosák (a podle něj někteří další). Avšak k tomuto roku je datován alianční erb Licků a Zejdliců, umístěný na druhé pernštejnské hradní bráně. ${ }^{49}$ Sňatek se přitom musel odehrát ke konci roku, nebot' ještě 22. července vystavila Ester s příjmením Rájecká městečku Doubravník privilegium, jímž mu za roční poplatek 60 zlatých povolila právo várečné na pivo pšeničné i ječné, svobodné šenkování tohoto piva v obvodu města

\footnotetext{
45 Eliščin sňatek dokládá mimo jiné pamětní deska nad vchodovými dveřmi na zámku v Slatině, datovaná do roku 1602 a opatřená erby obou manželů. Složení skupiny poručníků katarýnovských sirotků a statků je patrné z právních jednání, realizovaných po smrti Pavla Katarýna. Vjeho závěti, sepsané 6. února 1597 a uložené in: MZA Brno, fond G 7 - Listiny zemského soudu Brno, inv. č. 107, sign. II-37, kart. 8, jsou jako poručníci uvedeni první chot' Griselda, rozená Čejková z Olbramovic, Karel starší ze Žerotína, Jiří starší Čejka z Olbramovic, Jan Vanecký z Jemníčky, Jan starší Odkolek z Újezdce a Kryštof Katarýn z Kataru.

46 HONC, J.: Falešný moravský rytíř, s. 80-81.

47 Ottův slovník naučný, díl XXI., s. 71-72.

48 NA Praha, fond Genealogická sbírka Dobřenský, inv. č. 848.

49

VAŠEK, L. - KONEČNÝ, M.: Kryštof, s. 12.
} 
a stejně tak i volný nákup a prodej soli, ${ }^{50}$ a ještě 20 . ř́jna bylo do českých zemských desek zapsáno, že Estera, na onen čas panna Zejdlička a již nyní Rájecká z Šenfeldu potvrdila přijetí částky 500 kop míšeňských grošů, odkázaných jí Rudolfem ze Šenfeldu. ${ }^{51}$

Existují ale ještě další prameny, dovolující další zpřesňování data smrti Jana Rájeckého z Mírova. V první řadě jsou to dva listy, zaslané císařem Rudolfem II. Janově choti Ester Zejdlicové ze Šenfeldu 10. června, resp. 20. ř́ijna 1603, ${ }^{52}$ které dále posouvají Janovo úmrtí do první poloviny roku 1603. Vztahují se k pohledávce 37 kop míšeňských grošů, kterou vůči ní uplatňoval malostranský lékárník Jan Jiří Dyrynk. Panovník prvním listem nařídil Ester, aby mu uvedenou částku uhradila, poněvadž jest on v nemoci manžela tvého i tvé vám oboum lékařství $z$ apatyky své posílal a tím tobě i manželu tvému sloužil. Protože se tento pokyn minul účinkem, obrátil se císař o několik měsíců později na Ester znovu. Konstatoval, že Dyrynkovu žádost považuje za slušnou, poručil jí, aby apatykářovy nároky uspokojila, a zdůraznil, že nechce být touto záležitostí znovu zaneprázdňován. V tomto druhém listu se již hovoří o dluhu za věci apatykářské ku potřebě někdy manžela tvého $v$ nemoci jeho brané, což je formulace, z níž jednoznačně vyplývá, že Jan byl již tou dobou mrtev. Z listu červnového to sice podobně jednoznačným způsobem patrné není, avšak již sama skutečnost, že je adresován Ester a nikoliv jejímu manželovi, je poměrně výmluvná.

Zcela konkrétně je pak Janovo úmrtí zachyceno $\mathrm{v}$ jednom $\mathrm{z}$ dobře známých a zdařile editovaných diárií z počátku 17. století. Konkrétně se jedná o kalendářové zápisky Adama mladšího z Valdštejna, jenž si k datu 14. února 1603 lakonicky poznamenal: Pan Jan Rájeckej umřel v Praze v pět hodin ráno na pưl orloji. ${ }^{53}$ Zajímavé je, že tato zpráva prozatím unikla širší pozornosti historiografie. Je z ní patrné, že Jan zemřel v podstatě vzápětí (necelý měsíc) po přijetí do panského stavu, což byl také nepochybně důvod, proč nevykonal př́slušné právní kroky nutné k tomu, aby se jeho př́slušnost k českému panskému stavu stala definitivní a nezpochybnitelnou. ${ }^{54}$ Jan Rájecký se tak nakonec vlastně pánem nestal - podobně jako jeho předchůdce na Pernštejně, Pavel Katarýn, který rovněž obdržel od Rudolfa II. privilegium na panský stav, ale neměl již čas ho přetavit v reálný společenský vzestup. Udělení císařského majestátu a vstřícný postoj českých pánů k Janově společenskému vzestupu se tak zlomyslností osudu staly derniérou účinkování rodu Rájeckých na historické scéně.

Zbývá pozastavit se krátce u osudů dalších aktérů tohoto příběhu a stejně tak i Rájeckého pozůstalosti. Po Janově smrti byla poslední nositelkou rodového erbu jeho sestra Eliška, provdaná za Volfa Zikmunda Jankovského z Vlašimi. Její další osudy z písemných pramenů nevysvítají, zdá se ale téměř jisté, že se jí týká zmínka v zápiscích Karla staršího ze Žerotína, podle nějž se pan Jankovský nedostavil k postnímu zasedání zemského

\footnotetext{
50 Podrobněji k obsahu ŠTARHA, I.: Za nových vrchností, s. 144-145. Originál listiny a poškozený opis jsou in: Státní okresní archiv Ždár nad Sázavou, fond Archiv města Doubravník, Listiny, inv. č. 3 a a kart. 2, č. 105, ověřený opis je uložen též in: MZA Brno, fond G 1 - Bočkova sbírka, sign. 7710 (kolacionováno v roce 1735). Autor cítí potřebu poděkovat na tomto místě za pomoc mgr. Vítu Křesadlovi, řediteli SOkA Ždár nad Sázavou.

51 DZV 131, fol. H 11v.

52 RG 111, fol. 174v-175r, č. 39, fol. 271v, č. 39.

53 KOLDINSKÁ, M. - MAŤA, P. (eds.), Deník, s. 61. Jan tedy nezemřel na uherském tažení, jak uvedla např. SEDLÁČKOVÁ, Helena: Pohřební štíty z kostela Povýšení sv. Kříže v Doubravníku. Paginae historiae 18, 2010, s. 269.

54 Právní aspekty přijímání do panského stavu v době předbělohorské nastínil v základních obrysech STARÝ, M.: Rytírí, s. 246-248; TÝŽ: Cizozemci, s. 186-195.
} 
soudu v roce 1613, a to pro těžký nedostatek zdraví p[aní] manželky své..$^{55}$ Stejně tak se jí pravděpodobně týká i zmínka v moravském konfiskačním protokolu z roku 1623, v němž je v souvislosti s konfiskací statků zesnulého Volfa Zikmunda zmíněna jeho manželka, jež není při zdravém rozumu, nýbrž pomatená. Vydržovat ji měl její švagr a Volfův bratr Bedřich Jankovský. ${ }^{56} \mathrm{~V}$ protokolu je rovněž zmíněn její syn, u něhož mělo být dále zkoumáno, zda se provinil rebelií. ${ }^{57} \mathrm{O}$ jeho osudech není nic bližšího známo.

Ovdovělá Ester ze Šenfeldu se, jak již bylo výše opakovaně uvedeno, nedlouho po Janově smrti, koncem roku 1604, znovu provdala za Adama Lva Licka z Rýzmburka, př́íslušníka starobylého českého rodu, od druhé poloviny 15 . století počítaného k panskému stavu. ${ }^{58}$ Společně drželi pernštejnské zboží, přičemž v roce 1609 byla jejich držba podepřena intabulací kupní smlouvy ze strany Petra a Jana Katarýnů. ${ }^{59}$

V tomto ohledu se nabízí nanejvýš zajímavá otázka, jaký byl vztah mezi touto koupí a smluvním ujednáním z roku 1602, v němž vystupoval jako jediný kupec Jan Rájecký. Pokud byla původnímu právnímu vztahu přiznána platnost i po Janově smrti, pak měla Pernštejn zřejmě zdědit jeho sestra Eliška jakožto nejbližší příbuzná. Vdova Ester se jedinou majitelkou statku mohla stát jedině v případě, že by byl Jan býval sepsal kšaft (testament), což ale prameny nedokládají. A kdyby se tak bylo bývalo stalo, pak by zcela postrádalo smysl, aby byla sepisována nová kupní smlouva a v ní vedle Ester figuroval i Adam Lev Licek. Jeho potenciální nárok pro případ Esteřiny smrti mohl být snadno zabezpečen uzavřením spolku, k čemuž ostatně také vzápětí došlo. Na druhou stranu, není jasné, na jakém základě by původní smlouva měla být považována za neplatnou a o jaký právní titul by se v takovém případě opírala držba Ester Rájecké, znovu provdané Lickové ze Šenfeldu v mezidobí let 1603-1609. Zdá se tedy nejpravděpodobnější, že nová kupní smlouva byla prostě koncipována tak, aby Adam Lev vstoupil do totožného právního postavení jako Esteřin první manžel, a s jemnými právními nuancemi (a zejména formální kontinuitou právních poměrů) si nikdo přespříliš hlavu nelámal...

Adam na sebe výrazně upozornil v roce 1619, kdy po boku moravského stavovského plukovníka Albrechta z Valdštejna, pozdějšího frýdlantského vévody, dezertoval do Vídně i s částkou 96000 tolarů ukradenou ze zemské pokladny. Za to byl také společně s ním na věčné časy vypovězen z Moravského markrabství a jeho statky měly být zkonfiskovány. ${ }^{60}$ Fakticky ale toto sněmovní usnesení zřejmě realizováno nebylo. Na druhou stranu se Adam nedožil ani rehabilitace, ani deště milostí, jež se snesly na ty, jež zachovali věrnost

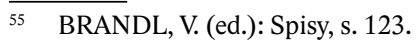

56 S Rajeckými spř́zněnému rodu Jankovských z Vlašimi věnoval monografii BOLOM, Sixtus: Tajemství Jankovských z Vlašimi a na Bítově. Třebíč 2008.

57 SLOVÁK, Jindřich (ed.): Pobělohorský konfiskační protokol moravský z r. 1623 : Konfiskations oder Cridae Prothocollum des Margrafthumb Mähren von Anno M-DC-XXIII. Kroměříž 1920, s. 13, 74.

58 V seznamu panských rodů intabulovaném v roce 1500 do českých zemských desek jsou Lickové uvedeni až na 43. místě, avšak ještě před čtveřicí rodů přijatých do panského stavu v roce 1479. Knihovna Národního muzea Praha, sign. I A 1, fol. 215v. Mylně tedy uvedl I. ŠTARHA (Za nových vrchností, s. 143-144), že Adam Lev Licek byl podobně jako Pavel Katarýn členem nově do šlechtického stavu povýšeného rodu, který získal Zikmundem Lickem šlechtický titul a erb, zlatý třmen v modrém poli, až v 16. století - v roce 1550. Vycházel možná ze starší práce R. PROCHÁZKY (Genealogisches Handbuch, s. 361), kde se rovněž objevuje údaj o potvrzení českého panského stavu v roce 1550 (erhielt 1550 eine böhm. Herrenstandsbestätigung), avšak s tím, že k stavovskému pozdvižení rodu Licků došlo již na počátku 16. století.

59 MZD III BR, kniha XXXIV (XXX), s. 374-375, č. 15.

60 Podrobněji např. DVORSKÝ, František: Albrecht z Valdštejna až na konec roku 1621 : Nové listy do knihy třistaleté paměti. Praha 1892, s. 98-103.
} 
císaři. Již 11. března 1620 totiž zahynul jako podplukovník Valdštejnových valonských rejtarů v potyčce poblíž dolnorakouského Maissau. ${ }^{61}$

Podobně jako s Janem Rájeckým, nedočkala se Ester Zejdlicová ze Šenfeldu potomstva ani s Adamem Lvem Lickem. ${ }^{62}$ A tak se historie zanedlouho opakovala a pernštejnské zboží se dočkalo nového pána, který se na ně přiženil - tentokrát se jím stal původem tyrolský šlechtic, hrabě Kryštof Pavel z Lichtenštejn-Castelcornu († 1648). ${ }^{63}$ Ke sňatku došlo někdy v letech 1622-1623 a již 30. července 1623 sepsala Ester testament, jímž Pernštejn odkázala právě svému třetímu choti. ${ }^{64} \mathrm{O}$ dva roky později ho pak ještě přijala na pernštejnské zboží na spolek, ${ }^{65}$ čímž se de iure stal jeho spolumajitelem. Ester zemřela zřejmě na počátku 30. let 17 . století, nebot její poslední manžel vydal 15 . února 1631 sám privilegium pro městečko Doubravník, jímž mu potvrdil starší Esteřiny výsady, tj. právo držení a užívání zdejšího pivovaru za roční poplatek 60 zlatých. ${ }^{66} \mathrm{~V}$ rodě Lichtenštejn-Castelcornů pak zůstalo pernštejnské panství až do roku $1710 .{ }^{67}$

V té době zůstaly však již po rodu Rájeckých jen vybledlé vzpomínky a zaprášené písemnosti, nijak zvlášt' četné, s jejichž pomocí lze jen torzovitě rekonstruovat osudy jednotlivých příslušníků rodu. Platí to i pro posledního mužského potomka Jana, kterému vyšla sázka na vojenskou službu vládnoucí dynastii a dopracoval se k vzestupu jak majetkovému (koupě panství Pernštejn v roce 1602), tak sociálnímu, když obdržel v roce 1602 z říšské kanceláře majestát na panský stav a počátkem roku 1603 ho na zemském sněmu přijali do svých řad shromáždění zástupci panského stavu Českého království. Vzápětí mu však bohyně Fortuna ukázala odvrácenou tvář, když ho jen necelý měsíc po posledně uvedeném právním aktu v mladém věku stihla nečekaná smrt. Povýšení, resp. přijetí do panského stavu tak poněkud paradoxně napsalo epilog rodových dějin. Zajímavé je, že nešlo o úkaz ojedinělý - podobným způsobem se jen o málo později uzavřely osudy

${ }_{61}$ DVORSKÝ, F.: Albrecht, s. 113; KNOZ, Tomáš: Pobělohorské konfiskace : Moravský průběh, středoevropské souvislosti, obecné aspekty. Brno 2006, s. 140.

62 DVORSKÝ, F.: Albrecht, s. 113, uvedl, že Adam Lev zanechal s Ester ze Šenfeldu dvě děti- Ladislava († 1632), který byl služebníkem Valdštejnovým a držel frýdlantské léno Bílá Třemešná, a Annu Marii. Ve skutečnosti byli ale Ladislav a jeho sestra pouze Adamovými kolaterálními př́ibuznými a jejich otcem byl Vratislav Václav Licek z Rýzmburka († 1619). Ladislav po něm zdědil statek Petrovice, který nechal v roce 1624 vložit do desk Karlovi z Lichtenštejna. DZV 142, fol. B 21r - B 22r; DZV 293, fol. C 4v-C 5v. O tom, že Ladislav nebyl synem Ester ze Šenfeldu, svědčí neprímo i skutečnost, že podle kupní smlouvy měl Lichtenštejn smluvenou cenu 5430 kop míšeňských grošů vyplatit Albrechtovi z Valdštejna a postoupení statku měl provést tentýž Albrecht coby Ladislavův poručník.

63 Kosobě Kryštofa Pavla podrobně zejména VAŠEK, L. - KONEČNÝ, M.: Kryštof, s. 7-35.

64 MZA Brno, fond G 263 - Rodinný archiv Podstatských-Lichtenštejnů, Telč, inv. č. 24, kart. 6, sign. B 5. Pokud se v textu závěti výslovně uvádělo, že Ester o veškerém svém majetku rozhodla s ohledem na vždycky $k$ sobě věrnou a upř́mnou manželskou lásku od urozeného pána, pana Kryštofa Pavla hraběte v Lichtenštejně, svobodného pána $v$ Kastelkornu, je třeba to hodnotit spíše jako zažitý kurtoazní obrat, protože manželství skutečně nemohlo být uzavřeno dlouho před sepsáním poslední vůle.

65 MZD III BR, kniha XXXVI (XXXII), s. 485, č. 3.

66 SOkA Žd'ár nad Sázavou, fond Archiv města Doubravník, Listiny, inv. č. 5. Že Ester zemřela po roce 1630 , uvádějí L. VAŠEK - M. KONEČNÝ (Kryštof, s. 11. 35). H. SEDLÁČKOVÁ (Pohřební štíty, s. 269) datovala její smrt rokem 1636 jako termínem ad quem, zdá se ovšem nepochybné, že v době konformace doubravnického privilegia hrabětem Kryštofem Pavlem byla již po smrti. Jako žijící je zachycena naposledy v roce 1630, kdy vystavila společně s manželem dlužní list Karlovi Grýnovi ze Štyrcenberka a jeho manželce. MZA Brno, G 263 - Rodinný archiv Podstatských-Lichtenštejnů, Telč, inv. č. 63, kart. 2 (stará sign. 19).

67 Dlužno dodat, že další majitelé Pernštejna nebyli potomky hraběte Kryštofa Pavla, nebot ten nezanechal potomstvo ani se svou druhou chotí, hraběnkou Maxmiliánou Markétou ze Salm-Neuburgu († 1663), a svá panství odkázal synovci Maxmiliánovi. V mužské linii vymřel rod Lichtenštejn-Castelcornů v roce 1762. 
Nekšů z Landeka, když poslední mužský příslušník rodu Václav obdržel císařský majestát v roce $1604,{ }^{68}$ zemřel však již o tři roky později ${ }^{69}$ Pouhé dva roky dělily také povýšení a smrt posledního člena dalšího starého moravského rodu Drnovských z Drnovic (1617-1619)..$^{70}$

Tyto případy, kdy vzestup byl vzápětí vystřídán definitivním pádem, ovšem nepředstavují v kontextu opakovaně již popsaného demografického vývoje české šlechty na sklonku 16. a počátku 17. století nic překvapivého. Vymírání starobylých aristokratických rodin vedlo k zintenzivnění přijímání rytírư do panského stavu, přičemž ovšem i některé z nově přijatých rodů již pozbyly vitálnosti a směřovaly ke svému biologickému zániku.

V případě Rájeckých z Mírova byla souslednost přijetí a vymření extrémně krátká, takže Jan Rájecký již ani neměl čas podniknout kroky, jimiž by svůj sociální vzestup dovršil (přiznání ke stavu, prokázání urozeného původu). Proto také dosavadní odborná literatura jeho přijetí mezi české pány víceméně opomíjela, stejně jako jeho rovněž velmi epizodickou vládu nad pernštejnským panstvím. Předkládaný příspěvek se pokouší tento dluh poněkud zmenšit, aniž by tím byl ale vyčerpán prostor pro pátrání po dalších střípcích, jimiž by mohla být mozaika dějin rodu Rájeckých z Mírova dále doplňována.

\section{Summary}

\section{Granting Lordship and Admission to the Estate of Lords as both the Peak and the Epilogue of Rájeckýs' of Mírov Family History}

At the end of the 16th century, it became increasingly common for Czech kings of the Habsburg dynasty to issue royal decrees of ascension by which they elevated their addressees to the lordly state in addition to the traditional grants of arms. Some of these royal decrees were issued by the Czech court office, other documents were written by the imperial office and their issue was therefore exercised not by the Czech royal but by the imperial power. However, since the Czech aristocracy were probably particularly sensitive to their exclusive right to approve new members of the nobility, the recipients of both types of documents were mostly Moravian and Silesian knights. Nevertheless, it should be noted that as in Bohemia, this privilege did not guarantee its addressee entry into the higher nobility in Moravia - the decisive factor was the position of the manor curia itself at the Diet.

The names of recipients of royal decrees of ascension under imperial provenance include Jan Rájecký of Mírov, the last member of an ancient but not particularly affluent or influential Moravian family. He was elevated to the lordly state by Emperor Rudolf II on April 10, 1602 (in this case, the decree issued by the imperial office). The reason, which was also partially explained in the text of the decree, was Jan's military service provided to the Habsburgs mainly in connection with the ongoing conflict with the Ottoman Empire which permanently threatened the eastern border of their territories.

Immediately after receiving the diploma, Jan, who sold the inherited Osová estate (nowadays Osová Bitýška) right after coming of age and held and only small and completely insignificant estates in Moravia since then, drew considerable attention by purchasing the large Pernštejn estate with 2 towns and 39 villages from the indebted estate of the former provincial burgrave and viceroy of the

68 NA Praha, fond Salbuchy, kniha č. $12 \mathrm{~b}$, inv. č. 3, fol. $805 \mathrm{v}-807 \mathrm{v}$.

69 Prostřednictvím jeho neteře Lukrécie se pak nástupcem Nekšů stal budoucí frýdlantský, meklenburský, zaháňský a hlohovský vévoda Albrecht Václav Eusebius z Valdštejna. Podrobněji např. JANÁČEK, Josef: Valdštejn a jeho doba. Praha 1978, s. 74-91.

70 Drnovského povýšení viz NA Praha, fond Česká dvorská kancelář, sign. IV D 1, inv. č. 752, kart. 512; fond Salbuchy, kniha č. 22, i.č. 8, fol. 249r-253v. Podle KOLÁŘ, Martin-SEDLÁČEK, August: Českomoravská heraldika, [I]: Část všeobecná. Praha 1902, s. 129, měl Jan Drnovský zemřít v roce 1620. Avšak ve skutečnosti k tomu došlo již přechozího léta, nebot' již 16. prosince 1619 se jeho sestry Kateřina a Johana, resp. jejich manželé porovnali o pozůstalost po něm. MZA Brno, A 12 - Akta šlechtická, kart. LXI, sign. 1/1a. 
supreme clerk, Pavel Katarýn of Katar. Rájeckýs tenure of Pernštejn is often neglected due to its episodic nature but it is undoubtedly evidenced by several sources. Among them was a purchase contract stating that the estate would be handed over in May of 1602 and that the buyer would pay a large part of the 20000 gold coins in cash. Although there is no doubt that military service may have been a fairly lucrative source of income for some officers, it can be hypothesised that Jan's sudden rise may have been connected the marriage he entered in 1602. His chosen one, Ester Zejdlicová of Šenfeld, was one of the numerous descendants of the affluent Czech chamberlain and chief governor of all imperial estates in the Czech Kingdom, Hertvík Žejdlic. The fact that her share in the purchase of the Pernštejn estate was definitely not negligible is best evidenced by the fact that after Jan's death, it remained in her possession and she brought her second husband there.

Jan tried to fructify the decree of ascension granted by the emperor by asking to be accepted among the lords at the Land Diet - surprisingly not in Moravia but in Bohemia. This happened at the beginning of 1603 but the lord of Mirov was no longer able to complete this rise in status which had to be registered in the land records (Desky zemské). He died soon after.

The exact date of Jan's death was unknown in existing genealogical literature even though it is explicitly stated in the notes of Adam the Younger of Wallenstein. The given date - February 14, 1603, is indirectly confirmed by other sources which narrow down the day of Jan's demise to the early months of that year. That is why the vast majority of authors missed Jan's episodic, several-month-long tenure of Pernštejn. With Jan's death, the Rájeckýfamily became extinct. Here we can observe an interesting but most likely accidental correlation with several other Moravian families where admission to the estate of Lords also became a harbinger of an early end (Nekšové of Landek, Drnovští of Drnovice).

The aim of the study is to present the fate of the last member of the Rájecký family, to place his efforts for social ascension into a more general context and thus to contribute a small snippet to our knowledge of the early modern elites of the Czech state. The study also includes editions of the degree of ascension by Emperor Rudolf II from April 10, 1602, and its Czech translation which was made for reasons which are not entirely clear but which has been preserved in two copies (one of which is, however, incomplete). 


\section{Př́loha}

\section{Německý a český text majestátu na stav svobodných pánů pro Jana Rájeckého z Mírova}

Pozn. Německý text byl z předlohy v zásadě transliterován, upraveny byly v souladu se současnými pravopisnými pravidly pouze psaní velkých a malých písmen a užívání hlásek $u$ a $v$. Český text byl naproti tomu transliterován, přičemž i zde bylo ovšem snahou v maximální únosné míře zachovat původní ráz textu. Modernímu pravopisu bylo přizpůsobeno oddělování jednotlivých slov, psaní velkých a malých písmen, užívání dlouhých a krátkých samohlásek a stejně tak kolísání samohlásek $i-y$, odbouráno bylo užívání w namísto dnešního $\mathrm{v}$ a stejně tak $v$ místo fonetického $u$. Redukováno bylo foneticky irelevantní zdvojení souhlásek $d, f, l, s$ a $t$, naproti tomu zdvojené $s$ naznačující změkčení bylo převedeno na š. Také spřežky vyjadřující změkčení $(c z, r z)$ byly přepsány podle moderního pravopisu $(\check{c}, \check{r})$, spřežka $c z$ byla v ostatních případech redukována na $c$. Dvojhláska $g k$ byla přepsána jako $k$, koncové $i i$, resp. $i j$ podle okolností jako $i$ nebo $i$. V souladu s fonetikou bylo řešeno kolísání grafémů $g$ a $j$ a užívání y namísto $j$ (především v dvojhlásce ey, transkribované jako ej). Hláska $z$ byla dle současných pravidel eventuálně přepsána jako ž, bylo-li změkčení naznačeno následujícím $i$, toto bylo redukováno, stejně jako v jiných případech, kdy v hláskové skupině hraje změkčující úlohu bez samostatného fonetického projevu. Písmena ie byla coby digraf přepsána jako ě, v př́padě jotace však jako $e$. Diftong $a u$ byl v relevantních př́padech modernizován na ou, historický diftong uo byl naproti tomu zásadně ponechán.

\section{Wir, Rudolff der Ander etc.}

Bekennen für Unns, und Unsere Nachkhomen am Reich, und Unserm löblichen Hauß Österreich offentlich mit disem Brieff, und thun kundt allermenigelich. Wiewol die höhe römischer kayserlicher Wirdigkait, durch Macht Ihres erleuchtes Throns, hievor mit edlen Geschlechten und Unterthanen geziert ist. Jedoch weil dieselben durch Absterben der Menschen, ye zu Zeiten in Abnemen komen, und ye mehr die kayl: Hahait solche Geschlecht, ihrem ehrlichen adelichen Herkomen, Wolthaten und Verdienen nach zu höhern Ehren und Wirden erhebet, ye mehr dardurch der Thron kayl: Mayestatt geziert, und Iren getreuen Unterthanen zu guten, redlichen, adelichen Tugenten und Thaten Anraizung und Ursach gegeben würdt.

Und Wir dann gnedigelich angesehen, wahrgenomen und betrachtet, daß alt adelich gegen Unns und Unserm löb: Hauß Österreich wol affectionwerte, und mit Herrn Standts Personen befreundete Geschlecht, darinn Unser getreuer lieber Johan Ragezky von Mirav auf Per[n]stain und seine Vorelltern herkomen, insonderheit aber die angenemen, getreuen, aufrichtigen, redlichen, dapffern und unverdroßne Dienst, so weillendt sein Vatter Marquart Rageczky von Mirav Unsern hochgeehrten Voreltern, und nach rhumlichem Exempel derselben auch er Johann Rageczky, Unns in vil unterschidliche Weeg, und darunter von Anno 1592. und also von Anfang Unseres wider gemainer Christenheit Erbvheindt den Türckhen füerenden Kriegs über biß daher, und zwar mit Bedien: und Versehung fürnemer Beuelch, zu Unserm, auch obersten Generals und freundtlichen geliebten Bruders, Erczherczog Matthiasen zu Österreich etc., inmassen ime dessen von S.r L: sondere lobwirdige Kundtschafft gegeben würdt, gnedigistem Wolgefallen und benuegen, nach pesten Vermögen, und ritterlicher Dapfferkait erzaigt und beristen hatt, dasselbe noch täglichs thutt, und hinfüro mit gleichmässigem rhumblichem Eyfer zuthun unterthenigist erpietig ist, auch wol thun kan, mag und soll.

So haben Wir demnach mit wolbedachtem Mueth, gutem Rath, rechter Wissen und auß selbs aigner Bewögnus, obgenantem Johann Rageczky dise besondere Gnadt gethan, und 
ime sambt seinen ehelichen Leibß Erben, und derselben Erbens Erben seines Namens und Stammens, Mann und Frauen Personen, auß römischer kayl: und königelicher Macht, in den Standt, Ehr, Wirde, Gemainschafft, Schar und Gesellschafft der gebornen Freyherren und Freulin erhebt, gefreyt, gewirdigt und geseczt, und andern Unsern und des Heyl: Reichs, auch Unserer Königreich, erblichen Fürstenthumb und Landen gebornen Freyherrn und Freulin gegleicht, zugefuegt und zugestellet, allermassen, als ob sy von ihren vier Ahnen, Vatter und Muetter und Geschlechten, zu baiden Seiten recht geborne Freyherrn und Freulin wären.

Thun das, erheben, befreyen, wirdigen, seczen, gleichen, zufuegen und gestellen sy auch also in den Standt, Grad, Ehr, Wirde, Gemainschafft, Schar und Gesellschafft Unserer und des Heyl: Reichs, auch Unserer Königreich, Erblichen Fürstenthumb und Landen Freyherrn und Freulin.

Und meinen, seczen und wöllen, von derselben Unser kayl: und königelichen Macht, daß obgenanter Johann Rageczky von Mirav, auch seine eheliche Leibß Erben und Nachkhomen, in absteigender Linj, seines Namens und Stammens, Mann und Frauen Personen, für und für ewigelich, Freyherrn und Freulin sein, und sich nun hinfüro Freyherrn und Freulin von Mirov nennen, haißen und schreiben, von Unns, Unsern Canczleyen, und sonst menigelich also genent, geschriben und darfür gehalten werden, auch alle und yedeliche Gnadt, Freyhait, Privilegien, Herrlichaiten, Altherkomen, Statuten, Gewonhaiten, Gesellschafft, Ehr, Wirde, Vorthl, Recht und Gerechtigkhait haben, mit Beneficien auf Thum Stifften, hohen und nidern, auch andern ehrlichen Ämptern geistlichen und weltlichen, und insondrhait Herrn auch Paner und Freyherrn Lehen und Affter Lehen, zuempfahen und zutragen, deßgleichen in Versamblungen, Gesellschafften und Gemainschafften und sonst inner: und ausserhalb Gerichtes, in allen und yeglichen ehrlichen, redlichen, Sachen und Geschäfften zugelassen, Standt, Session und Zugang haben, darzu tauglich geschickt und guet sein, und sich solches Freyherren Standts, nach ihren Ehren, Notturfften, Willen und Wolgefallen freuen und gebrauchen sollen und mögen, wie andere Unsere und des Heyl: Reichs, auch Unserer Künigreich, erblichen Furstenthumb und Landen, geborne Freyherrn und Freulin solches alles haben, sich dessen freuen, gebrauchen und genießen, von Recht oder Gewonhait, von allermenigelich unverhindert.

Doch solle dise Unsere Erhebung und Befreyung Unns, denn Heyl: Reich, auch Unsern Kunigreichen und löblichen Hauß Österreich, an dessen Freyhaiten, Rechten, Gerechtigkaiten, Erb: und Lehenpflichten unverleczlich und ohne Schaden, auch mehrgedachter Johann Rageczki Freyherr von Mirov, seine eheliche Leibß Erben und Nachkhomen, yederzeit schuldig und pflichtig sein, irer Güetter halben, so sy in Unsern Fürstenthumben und Erblanden haben, oder künfftigelich überkomen mähten, neben andern getreuen und verpflichten Landtleuthen und Unterthanen, mit Gehorsam Steur, Raisen und andern gemainen Bürden, Gaben und Handtraichungen, in alleweg zuheben und zulegen, und neben dem schuldigem gehorstem Gepürlichs mitleiden zutragen, ohne Gefehrde.

Und gepieten darauf allen und yeden Churfürsten, Fürsten, geistlichen und weltlichen, Praelaten, Graven, Freyen Herrn, Rittern, Knechten, Landteßhauptleüthen, LandtMarschalchen, Hauptleüthen, Viczdemben, Vögten, Pflegern, Verwesern, Amptleüthen, LandtRichtern, Schuldthaissen, Burgermaistern, Richtern, Räthen, Burgern, Gemainden und sonst allen andern Unsern und des Reichs, auch Unserer Künigreich, erblichen Fürstenthumb und Lande, Unterthanen und Getreuen, was Wirden, Standt oder Wesens die sein, ernstlich und vesstigelich, mit disem Brief und wöllen, daß sy offtbemelten Johann 
Rageczki Freyherrn von Mirav, auch seinen ehelichen Leibß Erben und derselben Erbens Erben bayderley Geschlechts, für und für in ewig Zeitt, Freyherrn und Freulin, wie obsteth, schreyben und nennen, und also in allen und yedlichen ehrlichen ritterlichen Sachen, Handlungen und Versamblungen, Ämptern, geistlichen und weltlichen, auch auf Thum Stifft und sonst allen andern Ortten und Enden, nichts außgenomen, zulassen, darfürachten, erkennen, ehrn und halten, auch aller und yeder Ehr, Wirde, Praeminenz, Vorthl, Recht und Gerechtigkaiten, freuen, gebrauchen und geniessen, und an dem allem nit hindern noch irren, sonder sy dabey genczlich bleyben lassen und hiewider nit thuen, noch des yemandts andern zuthun gestatten, in khain Weyß noch Weeg, als lieb ainem yeden sey, Unser und des Reichs schwäre Ungnadt und Straff und darzu ain Peen, nemblich hundert Marck löttiges Goldts zuvermeiden, die ain yeder, so offt er fräuentlich hiewieder thette, Unns halb in Unser und des Reichs Camer, und den andern halben Thail, vilgenantem Johann Rageczky Freyherrn von Mirov[,] seinen ehelichen Leibs Erben und Nachkomen, unnachläßlich zubezalen verfallen sein, solle.

Mit Urkhundt diß Briefs, besiglt mit Unserm kayl: anhangenden Insigl.

Datum zu Prag den 10. Aprilis A[nn]o 1602.

My, Rudolf Druhý, z Boží milosti volenej římskej císař, po všecky časy rozmnožitel říše, uherskej, českej, dalmatskej, charvatskej, slovanskej král etc., arcikníže rakouzské, kníže burgundský, brabantský, štýrský, korytanský (sic!), kranský, lucemburský, virtmberský a v Horním i v Dolním Slezště, též kníže švábský, markrabě Svaté ř́mské ř́še burgavský, moravský a lužický, hrabě habšpurský, tyrolský, pfirtský, kyburský a gerský, landkrabě elsaský, pán v Vindišmarku, v Portenav a v Salinsu etc.

Vyznáváme za sebe i za potomní rímský císaře i z našeho slavného domu rakouzského potomky přede všemi tímto listem. Ačkoliv slavná císařská jasnost skrze moc slavnýho trůnu svého předešle urozenejmi rody a poddanejmi jest ozdobena. Však poněvadž ti skrze smrtedlnost lidskou časem $k$ zmenšení pricházejí a čím více císařská velebnost takový rody pro jich poctivé a urozené zrození a zásluhy $k$ vyžším poctivostem a zvejšením vyzdvihuje, tím více skrze to trůn císařský velebností se ozdobuje a jich věrnejm poddanejm k dobrejm, statečným, šlechetným mravưm a činům chut' a príčina se dává.

I šetříce My milostivě na starožitnej a k Nám i k Našemu slavnému domu rakouzskému vždycky poslušnej, taky i s osobami stavu panského nejednou zpř́zněnej rod Našeho věrného milého Jana Rájeckého z Mírova na Pernštejně, a pro ty věrný, upřímný, statečný a neustálý služby, kteréž někdy otec jeho Markvart Rájecký z Mírova Našim vzáctnejm předkuom činil, a jeho př́kladem on Jan Rájecký, syn jeho, v mnohejch rozdílnejch spüsobích Nám činí, obvzláštně pak, že od začátky (sic!) války Naší proti všeho křestanstva nepřiteli Turku předsevzatý až do tohoto času v spravování předních vojenských ouřaduov neustále trvajíce, $k$ Našemu, též $i$ nejvyžšího generála, Našeho milého bratra, arciknížete Matyáše Rakouzského (tak, jakž se mu od Jeho Lásky obvzláštní chvalitebný svědectví o tom vydává), $k$ milostivému Našemu zalíbení vedlí svý nejvyžší možnosti a rytířský statečností ustavičně Nám sloužiti nepřestává a budoucně touž poctivou horlivostí to činiti poníženě se zamlouvá, chce a motci bude.

Protož s rozvážlivejm rozmyslem, $s$ dobrou radou, pravou vědomostí a z Naší vlastní náchylnostinadepsanémuJanoviRájeckýmu tutoobvzláštnímilostčinitiajejsjehořádnejmi 
dědici i jich dědicův potomky, kteř́ž toho titule a rodu mužského i ženského pohlaví sou a budou, scísařský a královský mocnosti do stavu, poctivosti, vzáctnosti, společnosti a tovaryžstva urozených svobodnejch pánưv vyzdvihovati ráčime, jinejm Našim a Svatý ríše, taky Našich království, knížetství a zemí rozenejm svobodnejm pánům rovného jej činíce a knim ho přitovaryšujice, vším tím spůsobem, jako by po svejch štyrech dědích, votcích, mateřích a predcích z oboji strany pravě rození svobodní páni a svobodné paní byli. To My již tvrdíme, vyzdvihujeme anařizujeme. Takyvtenstav, stupeň, poctivost, vzáctnost, společnostatovaryžstvo jich je pripojujeme a Našim i Svaté ř́mské ř́iše, též království, knížetství a zemí Našich svobodnejm pánům a paním přitovaryšujeme. Chtíce tomu s císařský a královský motci, aby nahoře psaný Jan Rájeckej z Mírova i jeho pořádní dědicové a potomci tý linije mužskýho $i$ ženskýho pohlaví vždycky a na budoucí časy svobodní páni a svobodné paní byli a již se dále svobodní páni z Mírova jmenovali a jmenováni byli, vod Nás, od Našich kancelář́ $i$ ode všech vůbec. Taky $i$ všech milostí, svobod, privilejí, vzáctností, starobylého nařizení, zvyklostí, tovaryžstva, poctivosti, práva i spravedlností, též beneficí při kanovnictvích vyžšího i nižšího rádu, i jinejch poctivejch ouradech duchovních i světských aby užívali. Obvzláštně pak tak, jako jiní korouhevní a svobodní páni z strany prijímání manství, též ve všech shromážděních v tovaryžstvech, při soudech $i$ ve všech poctivejch vzáctnejch místech a potřebách téhož stavu a místa uživati mohli a tím svobodnejch pánův stavem vedle jich poctivosti, potřeby a vůle se těšili. Tak, jako jiní Naši a Svaté ř́še, též Našich království, knížetství a zemí rození svobodní páni a paní toho z práva a nebo zvyklosti užívají, beze vší každého člověka prekážky.

Však takové Naše v stav panskej vyzdvižení a osvobození Nám, Svatý ríši a Našim královstvím a zemím, též Našemu slavnému domu rakouzskému na svobodách, právích, spravedlivostech dědičnejch i manskejch povinnostech má bejti bez ubližení a škody. Nýbrž on Jan Rájeckej, svobodnej pán z Mírova, jeho pořádní dědicové a potomci každého času povinni budou z jich statkův, kterév Našich knížetstvích nebo dědičnejch zemích mají nebo budoucnějmíti budou, vedle jinejch věrných a Nám zavázanejch obyvateluov a poddanejch s poslušností berně dávati, jízdy činiti a jiná obecní břemena nýsti, též povinnou poslušnost a sjinejmi věrnost zachovati bez prerušení.

Protož všem i každému obzvláštně, kurfiřtům, knížatům, duchovním i světským, prelátům, hrabatům, svobodnejm pánům, rytíruom, zemanům, zemskejm maršálkům, hejtmanům, ouředníkům, správcím i soudcům zemským, také purkmistrům, rychtářom, konšelům a měštanům, vobcem $i$ všem jinejm, kteři Našemu císařství, též Našim královstvím, knížetstvím a zemím príslušejí, jakýchkoliv ti vzáctnosti, stavu a povolání jsou, př́stně a dostatečně tímto listem poroučíme a chceme, abyste nahoře psaného Jana Rájeckýho, svobodného pána z Mírova, taky i jeho pořádný dědice a jich potomky obojího pokolení vždycky na věčný časy, jakž svrchu dotčeno, svobodnými pány a paníma v psaních i v mluvení jmenovali, a tak ve všech poctivejch rytířskejch věcech, jednáních a ouradech duchovních i světských a všudy vi̊bec ve všech místech, nic nevyměňujic, za to je jměli, znali, ctili a drželi. Taky v každejch poctivostech ty vzáctnosti, práva a spravedlivosti svobodně jim užívati dali a v tom jim přkekážky nečinili, ani jinejm činiti nedopouštěli, než při tom jich dokonale zanechávali, pod uvarováním Naši těžký nemilosti a trestání, taky i pod pokutou sto hřiven čistého zlata, kderé jeden každej, kdož by se tomu svývolně na odpor postavěl, Nám polovici $k$ Naši ř́žský komoře a druhou polovici nahoře psanému Janovi Rájeckýmu, svobodnému pánu z Mírova, i jeho pořádnejm dědicům a potomkům bez prominutí propadnouti má. 
Toho na jistotu tento list Naší císařskou visutou pečetí jest stvrzen.

Kterejž jest dán na Našem královském hradu pražském 10. dne Aprilis po narození našeho milého Pána a Spasitele šestnáctistého a druhého líta, Našich království ř́mského XXVII., uherského XXX. a českého též XXVII. 